\title{
Notes to A.C.R.L. Board Members and Officers
}

$\mathrm{T}$ HE FOLLOWING memorandum, sent to A.C.R.L. board members and officers on May II, is published here with the thought that it may be of interest to all the members of the division. Please send your comments and suggestions to N. Orwin Rush, Executive Secretary, A.C.R.L., 50 East Huron St., Chicago I I, Ill.

\section{To A.C.R.L. Board Members and}

\section{OfFICERS :}

In a survey undertaken in 1947 by an A.C.R.L. committee to obtain membership opinion as to the most important activities of the association, publications ranked highest on the list.

With this information in mind I have made a special effort to encourage and initiate work along this line whenever possible. So that we may know what is actually underway or being considered for publication in the college, university and reference field, I list herewith items that have come to my attention.

It was my thought that if we had before us such a list we could better determine where the gaps are. Will you, therefore, please study this list and let me have your suggestions for needed publications not covered here.

\section{Projects now under way}

Administration. Guy Lyle is working on a second edition of his book. It will probably be published next fall.

Administration-Small Library. E. Hugh Behymer is writing a book on the administrative techniques for the small liberal arts college library.

Administration-Technical Processes. Maurice Tauber is at work on a book dealing with administration of technical services in libraries.
Archives-Manual. Librarian and archivist collaborating.

Bibliography. Henry B. Van Hoesen is working on a second edition of-his book.

Book List-Basic Reference Books. Louis Shores has completed the manuscript for a third edition of his book, and it is being examined.

Book List-Guide to Reference Books. Constance Winchell is working on a 7 th edition.

Cataloging-Special CollectionRare Books. A manuscript is in Mr. Fontaine's hands and is being examined by critics.

Circulation Work. Manuscript promised A.L.A. for spring or early summer of 1949. This will be a book of principles with illustrations drawn from various types of libraries so as to give the book general application.

Index-Guide to Comparative Literature. This is a project of the A.L.A., A.C.E., and the College Section of N.C.T.E. About 175 scholars are contributing to this work. Manuscript due at A.L.A. within a few months.

Order Work. Manuscript due at A.L.A. within next few months.

Reference $W$ ork-Study of Evaluation and Costs. Something under way at Columbia. Approach has been made to four other graduate library schools to see if ways can be found for attacking this problem.

Reference Work-Subject Guide to Reference Books. Herbert Hirshberg is working on a second edition of his book.

Resources-American Library. Robert Downs is working on a guide.

Shelf $W$ ork. William Jesse is now at work on the manuscript.

Other Proposals

Book List-Books and Serials for $A$ and $M$ Colleges. This suggestion, by Donald Thompson, has been referred to the A.C.R.L. Publications Committee. 
Book List-Junior Colleges. This suggestion is now being studied by the Junior College Libraries Section and the American Association of Junior Colleges.

Circulation-Interlibrary Loans. Carl Melinat is working on a Master's thesis out of which might grow a manuscript for publication.

College Libraries-Instruction and Book Use. B. Lamar Johnson may draw up a project for foundation financing. By survey, questionnaire, etc., he would try to determine and report on what is going on to integrate the teaching program with the use of library materials.

Finance and Accounting-College Libraries. This book was proposed some time ago by Donald Thompson.

Index-Learned Society Publications. Louis Shores has done some work on this and expects to give it more attention now that the manuscript for the third edition of Basic Reference Books is completed.

Serials Work-Manual. The A.L.A. Editorial Committee has received suggestions from a number of official groups regarding the need for and content of such a manual. As yet no one has been found to write it.

Statistics-Manual. Very little actual work has yet been done but a good deal of thought has gone into this project on which A.L.A. has been working since 1935. The A.L.A. Editorial Committee has decided that this should not be a book about statistics but a compendium of applications of statistical methods to library situations and library data. The introduction will have only enough theory to make the applications understandable. Edward Wight and G. Flint Purdy will attempt to develop the manuscript.

\section{Men Who Control Our Universities}

"The most exhaustive survey of university trustees that has yet appeared. . . . A scholarly approach to a controversial subject."-Benjamine Fine, N. Y. Times.

A College Program in Action: A Review of Working Principles At Columbia Col. lege. Prepared by the Committee on Plans.

$\$ 2.00$

College Retirement and Insurance Plans.

By William C. Greenough

A complete survey and analysis, based upon information from 800 college and university presidents and business officers.

Trends in Engineering Education:The Columbia Experience. By James Kip Finch "Recommended to all persons interested in the education of scientists and engineers."-Journal of Chemical Education.

\section{The Columbia Encyclopedia}

"The first one-volume encyclopedia in English worthy of the name." $-N$. Y. Times. $\$ 19.50$
The Columbia Dictionary of Modern European Literature Horatio Smith, General Editor. Covers authors and literature of Continental Europe from 1870.

$\$ 10.00$

Write for textbook catalogue

\section{COLUMBIA UNIVERSITY PRESS}

2960 Broadway

New York 27, N.Y. 


\section{For Quality Service in Library Erection}

Consult VIIRGINIA METAL PROIDUCTS

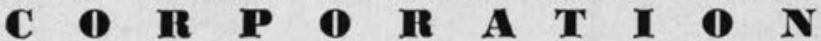

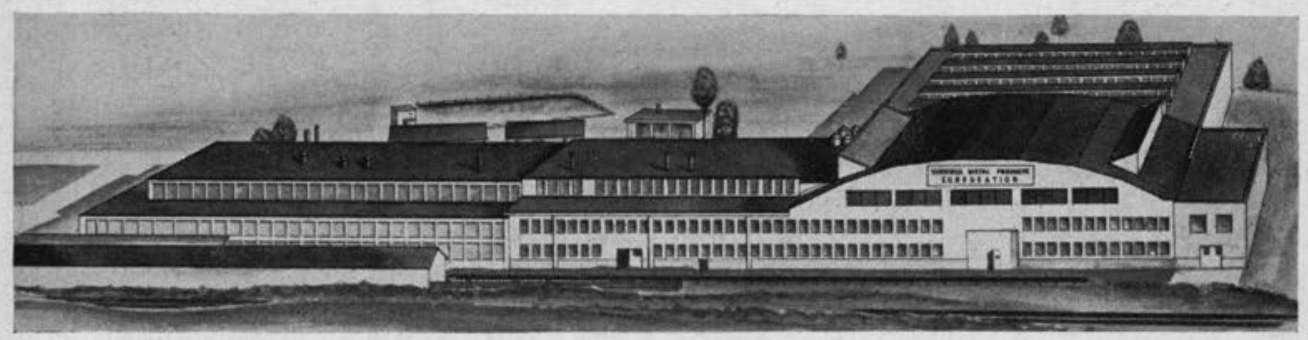

\section{It Actually Costs Less to Have the Leader in the Field Meet Your Specifications!}

Virginia Metal Products Corporation is internationally known for the quality and expert design of its library products.

For over fifty years, VMP installations have withstood the test of time. Only sincere effort, combined with craftsmanship and skill could have produced such results. In the long run you save by consulting the best in the library field.

The type of library work recently completed and now underway is proof of the outstanding recognition now enjoyed by VMP.

A contract with VMP means expert engineering, manufacture, estimate and erection by one firm. Those who demand the best consult Virginia Metal Products Corporation (Library Products Division).
VMP craftsmanship has recently been employed, or is now being utilized, in the following projects:

Sacred Congregation of the Oriental ChurchCompletion Vatican City, Rome, Italy Library Addition, University of Washington Seattle, Washington Library, Florida Agricultural \& Medical College The University of Texas Tallahassee, Florid Carson-Newman College Austin, Texas Jefferson City, Tennessee Medical College of Virginia Hospital Division, Richmond, Virginia Law School, South Carolina State A. \&M. Orangeburg. South Carolina Henderson State Teachers College Arkadelphia, Arkansas

Boston College School of Business Boston, Massachusetts University of South Carolina

Columbia, South Carolina Law Building. Richmond Public Library Richmond, Virginia New York State School for the Blind Batavia. New York

Addition, Obio State University-

Bookstack and Conveyor Columbus, Ohio Wright-Patterson Air Force Base

Sullins College Library

Dayton, Ohio

Law Building Bristol, Virginia

University of Virginia Law Library University, Virginis 